\title{
Value Clarification Technique Learning Model Based on Folklore towards Knowledge Competence of Civic Education
}

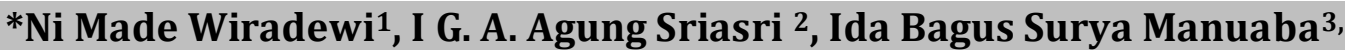 \\ 1,2,3 Program Studi Pendidikan Guru Sekolah Dasar, Universitas Pendidikan Ganesha, Singaraja, Indonesia
}

\author{
A R T I C L E I N F O \\ Article history: \\ 1 Mei 2020 Received in \\ revised form \\ 11 Juni 2020 \\ Accepted 10 Juli 2020 \\ Available online 25 Agustus \\ 2020 \\ Kata Kunci: \\ VCT, cerita rakyat \\ nusantara, PPKn \\ Keywords: \\ VCT, folklore archipelago, \\ $P P K n$
}

-

$\mathrm{dk}=\mathrm{n}_{1}+\mathrm{n}_{2}-2$ sehingga $\mathrm{H}_{\mathrm{o}}$ ditolak dan $\mathrm{H}_{\mathrm{a}}$ diterima. Maka dapat disimpulkan terdapat perbedaan yang signifikan kompetensi pengetahuan PPKn antara siswa yang dibelajarkan model pembelajaran Value Clarification Technique berbasis cerita rakyat nusantara dengan kelompok yang dibelajarkan melalui pembelajaran konvensional pada kelas IV SD.

\section{A B S T R A C T}

The low competence of civic education knowledge due to less optimal use of models when learning resulted that students have difficulty understanding learning and getting bored quickly. This study aimed to analyze the effect of the Value Clarification Technique learning model based on the civic on the knowledge competence of civic education. This study was a quasi-experimental research with nonequivalent control group design. A total of 184 students from 6th grade IV became the population. Samples were selected using a random sampling technique. Knowledge competence of civic education data collection used multiple-choice objective test instruments. The data obtained were analyzed using a t-test, namely polled variance. The results of data analysis obtained t-count $=2.880>$ $\mathrm{t}$-table $=2.005$ at a significance level of $5 \%$ with $\mathrm{dk}=\mathrm{n} 1+\mathrm{n} 2-2$ so that $\mathrm{Ho}$ is rejected and $\mathrm{Ha}$ is accepted. Then it can be concluded that there is a significant effect in the knowledge competence of civic education between students who are taught the Value Clarification Technique learning model based on the folklore.

\section{Introduction}

Indonesia is a developing country; thus, it is needed to conduct several improvements in all sectors, especially the education sector. Education is an important factor to improve a nation. Through an excellent education, qualified human resources who can bring the nation into a betterment are born. In conclusion, every country needs to have a good and qualified education. (Mulyadin, 2016) education can give birth to an educated layer of society and become a force that holds social units together in society. National education has a purpose to develop students' potentials to be a student who believes in God, has a noble character, is creative, independent, and becomes democratic and responsible citizen, the objectives of education indicate that in general, the goal of implementing education is the creation of 
quality and competitive human resources (Fitriani \& Sundawa, 2016). One of the problems which are faced by Indonesia is the low quality of education. Quality development can be implemented by using several ways. One of them is to develop the curriculum. The curriculum is a set of learning experiences that students will get during the educational process (Fujiawati, 2016). The curriculum has a powerful role of guideline in improving education quality by an evaluation in the education sector which is from KTSP to Kurikulum 2013. The 2013 curriculum is a set of learning content and science-based educational agendas provided by educational providers (Yusuf, 2018). The presence of Kurikulum 2013 is expected to complete the flaws of the previous curriculums. to develop and strengthen attitudes, knowledge, and skills in a balanced manner (Mirnasulistyawati et al., 2013). Curriculum 2013 implements the thematic learning system in which inside contains some of the subjects and gives full moral and values experience for the students. One of the subjects in the thematic learning is civic education. Civic education generally purposing on developing individual potential of Indonesian citizenship which is adequate and enabling to participate intelligently and responsibly in various life in society, nation, and state (Darmadi 2014; Sartika, 2018). Civic education is s a set of knowledge, skills, and students' basic values in understanding factual knowledge (Selly, 2019). Besides, citizenship education is a subject that focuses on forming citizens who understand and can exercise their rights and obligations to become smart, skilled, character Indonesian citizens mandated by Pancasila and the 1945 Constitution. In Elementary School, PPKn lessons are one of the lessons which are mandatory for students in preparing individuals who can be responsible for advancing and maintaining the integrity of the nation in the future from mutual competition between other countries.

Civic education learning in primary is also has a purpose to be learning process between teachers and students thus can form whole national generations that are expected to be able to build the character of the nation and state based on the 1945 Constitution, Pancasila and the norms found in society. Thus, the existence of civic education is expected to develop the attitude and moral change that leads to the national character. So that one of the successes felt by the community with the existence of PPKn is the development of changes in attitude and moral behavior that lead to the character of the nation. Based on the purpose, the civic education is important to be mastered by the students, to shape their personalities to be an exemplary and useful both for the community or nation and state under the values contained in Pancasila. In the civic education, teachers are pushed to be experts in mastering the values inside the civic education itself and implement the models which can boost the conducive and interactive learning atmosphere where the students can be actively seeking for their insight (Astawa, 2020). In reality, the civic education learning process prepares students to have excellent personalities. Civic education helps the students to have mutual respect and tolerance towards others who will be practiced in their daily lives ( Risvanelli, 2017). Teachers' role is pushed to create a happy, meaningful, challenging, and activating learning process. On the other hand, civic education is labeled as a difficult and boring subject and contains thick material. This makes the students are hardly master the material in civic education. This result of observation was gained from 2-5 October 2019 in the primary school at Gugus Sukawati VII, Kecamatan Sukawati education year 2019/2020. A lot of students do not get maximum marks in the civic education competency and the students barely understand the subject. This is because every student can deal with various difficulties, constraints, and psychological pressures (stress) in carrying out academic tasks (Jayanta \& Susiani, 2017). There are some factors, are: 1) Lack of model use or varied and innovative learning model, 2) Lack of enthusiasm and interest from the students in learning civic education, 3) Teacher centered learning, 4) Less conducive of learning atmosphere.

Teacher centered learning causes the learning atmosphere is less activating the students' motivation to be active in the teaching and learning process. Educators and learners are essential elements in the learning process. Teachers as the spearhead of learning must be able to plan and implement quality learning while students are the object of education as well as indicators of the success or failure of the educational process. As a teacher, it should be able to awaken the enthusiasm for learning and motivate students as effectively as possible to create a pleasant classroom atmosphere in synergy with students to produce the expected learning objectives (Kurniadi et al., 2020). As the facilitator, the teacher must know the job desc including providing the material, digging the students' potential in developing the students' potential, and educate the students. As the students, it must be realized that the main obligation is to study, which the teacher's main job is to facilitate. Student interest in learning is one of the factors supporting the success of learning and is very influential in student learning outcomes. To achieve optimal learning outcomes, many factors are involved. Some of them are curriculum factors, teachers, parents, and students themselves. The teacher does play an important role in the teaching and learning process because the teacher is the person who directly provides the subject matter to students so that the teacher is the main key in student learning success. In the learning process, the teacher should be 
able to organize learning materials and activities in such a way, to create a dynamic, innovative, and fun learning atmosphere. Teachers must also be able to apply appropriate teaching methods that involve students actively in the learning process. As a student, he is required to be an individual who directly carries out the learning process, so that students must be able to participate in active learning activities, be able to express ideas and be able to include all aspects that exist in him, including intelligence, interests, attention, motivation, methods, learning, and learning discipline. So that it will achieve satisfying learning outcomes. Learning discipline is one of the attitudes or behaviors that students must have. Students will get good results; this happens because students are less orderly and do not learn regularly. So that indicators of student learning discipline include adherence to satisfying learning rules if students can manage their learning time and activities. Tu'u (Agus, 2012) states that a good learning achievement is supported by a sufficient, good, and excellent level of intelligence, also supported by the existence of strict and consistent school discipline, individual discipline in learning, and also because of good behavior.

Based on these factors, the students' competency is directly influenced. To overcome these obstacles as educators should be able to use advanced creative models and methods in teaching. One of them is by increasing variations in learning such as the use of various learning models, attractive media, and appropriate methods. The learning model is a guide for teachers in designing learning activities. One of the innovative learning models that can be used is the Value Clarification Technique learning model. The Value Clarification Technique learning model or often abbreviated as VCT is a teaching technique to help students find and determine a value that is considered good in dealing with a problem through the process of analyzing existing and embedded values in students (Taniredja \& Tukiran, 2017; Nurdyansyah \& Fahyuni, 2016) VCT is also an educational approach where students are trained to find, choose, analyze, decide to take their attitude to the values of life they want to fight for (Adisusilo, 2014). VCT learning model has several advantageous features which are proposed by Castel (Adisusilo, 2014) students learn to communicate beliefs, values of life, dreams with peers, learn to empathize with other friends especially those with different beliefs, learn to solve moral dilemmas, learn to agree or reject group decisions, practice taking part in making decisions or defending or releasing beliefs. Meanwhile, Djahiri (Taniredja, 2017) propose some of the advantages of the Value Clarification Technique learning model including a) being able to build and foster values and morals in the internal side, b) able to describe and explain the essence of the material presented so that it makes it easier for teachers to convey messages, meanings et., al. and morals, c) be able to describe and assessing the quality of students' moral values, d) being able to give birth to, include, build and grow the potential of students especially potential attitudes, e) able to convey learning skills, f) able to prevent, cancel interventions and combine various moral values contained in students, g) provide information of moral values that deserve and guide and encouragement to live adequately and ethically.

(Risvanelli, 2017) states that This VCT learning model is applied using the group discussion method. Where students are divided into groups and given problems to analyze. After that, one group will present the results of the group's analysis, and the other group will respond to the results of the group's analysis that is presenting. In this study, utilizing the folklore of the archipelago in the delivery of the VCT learning model. In civic education, lessons contain life values such as morals, ethics, morals, and others that are widely found in the folklore of the archipelago. Using the VCT learning model and folk stories that function as a means of conveying values, students will become more interested in learning the content of civic education and be able to add insight and increase the competence of civic education knowledge. Folklore is half of Indonesia's cultural and historical wealth (Kristanto, 2014). Cultivating ethics from an early age is very important because, with an understanding of ethics, they will be careful when they behave. Ethical cultivation carried out by our ancestors in the past through oral tradition. One such oral tradition is folklore. Our ancestors taught ethics to their children through told folk tales alone. This is because, in the past, our ancestors could not write so that it was conveyed orally. This tradition is carried out from generation to generation, so that future generations can convey the story by word of mouth orally. Apart from being entertainment, folklore has the benefit of being used as role models, especially folk tales which contain messages of moral education (Isnanda, 2015). This model can provide values, moral learning to students who can shape the character and be useful in life. The study of the values contained in the folklore is of course very valuable for instilling ethics in children. By instilling ethics in children through folklore, it indirectly builds soft skills in them. This is supported by research (Astawa et al., 2020) entitled 'Civic Education Learning with VCT Model Loaded with Character Values to Increase students' Knowledge Competencies' which states that VCT learning influences on the civic education towards the students' civic education competency which is research. This study states that there are differences in PPKn knowledge competencies between students who are taught using the VCT learning model with character values and students who use conventional learning models (Astawa et al., 2020). This research has a connection with the research to be carried out, namely the use of VCT learning models 
and knowledge competence. Research carried out by (Siswinarti, 2019) entitled 'The Influence of the Value Clarification Technique Learning Model Providing Video on the Learning Outcomes of Civic Education' states that there are significant differences in civic learning outcomes between groups of students who are taught with the VCT learning model assisted by video media and groups of students who are taught using conventional learning models. This research is related to the research that will be carried out, namely the VCT and civic learning models, but this research uses video media as a means of delivering the material while the research carried out uses the basis of Indonesian folklore. This research was conducted to analyze the effect of the VCT learning model based on the folklore of the archipelago on the civic knowledge competency of grade IV SDN Gugus Sukawati VII Gianyar for the 2019/2020 academic year. From the results of research that has been done before, this study has differences with other research, namely from the teaching material, research subjects, research locations civic, and this research is based on folklore in the civic subject. Besides, this research innovates on the use of the basis of Indonesian folklore in the delivery of material and moral values in learning. This study will modify the steps of the VCT learning model according to Jarolimek (Taniredja et al., 2017) divided into 7 stages into 3 levels as described in table 01 . What will be added is the story of the archipelago which will be combined with VCT Steps.

Table 01. Stages of VCT Learning Model

$\begin{array}{ll}\begin{array}{l}\text { 1. The Free Choice } \\ \text { Stage }\end{array} & \begin{array}{l}\text { a. students are allowed to freely choose a problem that they think is good } \\ \text { b. students are given the freedom to choose choices that they think are good } \\ \text { c. students are given the freedom to choose after assessing the consequences } \\ \text { that will appear from their choice }\end{array} \\ \begin{array}{ll}\text { 2. The Respect Stage } & \text { a. There is a feeling of happiness and pride in students with the value they } \\ \text { choose so that these values will become part of the student } \\ \text { b. emphasize the value that has become part of the learners in public. }\end{array} \\ \begin{array}{l}\text { a. the desire and ability to try to carry out the choice of values in line with the } \\ \text { choice of students } \\ \text { b. Students are willing to repeat the attitude according to the value of their } \\ \text { choice and it is reflected in daily life. }\end{array}\end{array}$

With the implementation of this model, it is expected that the problem of civic knowledge competence at SDN Gugus Sukawati VII Gianyar can be resolved.

\section{Methodology}

The research used a quasi-experimental design. The quasi-experimental design used in this study is the Nonequivalent Control Group Design. This is due to the limited ability of researchers to monitor students' behavior when students are not in school. The research was carried out in grade IV primary students of Gugus Sukawati VII Kecamatan Sukawati academic year 2019/2020. The research began in September 2019 until March 2020. There were two groups in this design, which is the experimental group and the control group. The experimental group was given treatment, namely the VCT learning model based on Indonesian folklore, while the control group was given conventional learning. The research implementation was divided into 3 stages, namely the preparation stage, the implementation stage, and the end of the experiment. In the preparatory phase, the things done are determining the school that will be used as a place of research, conducting observations and interviews at the specified schools, determining the research sample, determining the research schedule, determining learning material, making lesson plans, worksheets and instruments, and consulting the instruments to the supervisors, and conducting instrument testing. The implementation phase is providing treatment of VCT learning based on the folklore of the archipelago in the experimental class and conventional learning in the control class each of 6 meetings. Furthermore, at the final stage of the experiment, the sample is given a post-test, analyze the results of the study, conduct a hypothesis test, and make a report.

The population of this research was all grade IV students of elementary schools at Gugus Sukawati VII with a total of 184 students from 6 classes with 6 different schools. After the population was determined, the research sample was determined. The part of the population that was considered representative of the entire population and was taken using a special technique was called a sample (Sugiyono, 2016). The sample was determined by a random sampling technique. The drawing was carried out so that all components of the population have the same opportunity to be taken as samples. The 
drawing was carried out 2 times, the first to determine the sample and the second to determine the experimental group and the control group. Based on the results of the first lottery, there were 2 sample groups for class IV SDN 1 Celuk and class IV SDN 3 Celuk. After getting 2 groups of samples then the equality test is tested first. After the equality test is completed, it will be drawn again to determine the experimental and control groups. Based on the results of the draw, SDN 3 Celuk was the experimental group, and SDN 1 Celuk was the control group. The experimental group was given action using the Value Clarification Technique learning model based on Indonesian folklore and the control group was given learning using conventional learning models. This study has 2 variables, namely the independent variable and the dependent variable. The independent variable of this research is the VCT learning model based on the folklore of the archipelago, while the dependent variable is the knowledge competency of civic education.

This study collected data on the knowledge competencies of the fourth-grade students of civic. The method used in data collection is the test method. The test used is a multiple-choice objective test (Multiple Choice Test) with 4 answer choices (A, B, C, D) with the most appropriate answer. Based on (Agung, 2014) The method used to obtain data can be in the form of tasks that must be done by participants, and the results obtained in the form of scores are called the test method. The test is a tool to estimate how far the student's expertise is in understanding the subject matter. So, the test method is used to obtain research data that usually measures the cognitive domain. The knowledge competency test developed is adjusted to the cognitive level of students. The measured basic competence is the benefit of the diversity of individual characteristics in daily life with a revised cognitive aspect of Bloom's taxonomy consisting of mentioning (C1), explaining (C2), determining (C3), and analyzing (C4). To ensure that the instrument has good quality, instrument testing is carried out in the form of validity testing, difference power test, difficulty level test, and reliability test. The validity test applies the content validity test and the item validity test. The validity of the content is the suitability of the material with the questions that will be given. (Arikunto, 2018) says if a test can calculate specific objectives on learning material, it is said that the test has content validity. While the validity of the objective test type is measured using the biserial point correlation coefficient formula (rpbi) because the test used is dichotomous. At a significance level of $5 \%$, it can be determined whether an instrument is valid or not by comparing the $r$-count with $r$-table. If $r$ count $>r$-table, it means that the instrument is said to be valid, and if $r$-count $<r$-table, it means that the instrument is said to be invalid. The validity test was carried out by consulting the instrument with experts in charge of civic and also conducting a trial test with the number of respondents 33 students. Of the 50 test items tested, 40 items were declared valid and 10 items were invalid. The grid used in this study was developed from the basic competencies for the civic content which were developed into 12 indicators.

Table 02. Preparation of Basic Competencies and Indicators for Civic Knowledge Competencies

\begin{tabular}{|c|c|c|}
\hline $\begin{array}{c}\text { Basic Competency } \\
\text { (BC) }\end{array}$ & Indicators & $\begin{array}{c}\text { Cognitive } \\
\text { Type }\end{array}$ \\
\hline $\begin{array}{l}\text { 3.1 Explain the benefits } \\
\text { of the diversity of } \\
\text { individual } \\
\text { characteristics in } \\
\text { everyday life }\end{array}$ & $\begin{array}{l}\text { 3.3.1 Mention the diversity of activities in the environment } \\
\text { 3.3.2 Identifying diversity images } \\
\text { 3.3.3 Describe the diversity of activities in the community } \\
\text { 3.3.4 Reviewing information about the diversity of tribes } \\
\text { and cultures in the surrounding environment } \\
\text { 3.3.5 Determine ethnic and cultural diversity } \\
\text { 3.3.6 Grouping religious celebrations in Indonesia } \\
\text { 3.3.7 Determining diversity in accordance with Pancasila } \\
\text { 3.3.8 Remembering the important days of diversity } \\
\text { 3.3.9 Analyzing the impact of diversity } \\
\text { 3.3.10 Understand the diversity of surrounding tribes and } \\
\text { 3.3.11 Mention attitudes in accordance with diversity } \\
\text { 3.3.12 Mention the diversity of religions in Indonesia }\end{array}$ & $\begin{array}{l}\text { C1 } \\
\text { C4 } \\
\text { C2 } \\
\text { C4 } \\
\text { C3 } \\
\text { C4 } \\
\text { C3 } \\
\text { C1 } \\
\text { C4 } \\
\text { C2 } \\
\text { C1 } \\
\text { C1 }\end{array}$ \\
\hline
\end{tabular}

The ability of the test items to describe the upper group test (smart) and the lower group test (weak) is called difference power. After carrying out the different power test, the test equipment difficulty index test and test items were carried out. The level of difficulty is the willingness or ability of students to answer a given test. The difficulty index ranges from 0.00 to 1.00 . The next stage after the difficulty index test is carried out is the reliability test. Reliability means consistency or regularity. The test is said to be 
reliable if it gives the right results if tested many times (Nurjanah \& Marlianingsih, 2015). The reliability test was carried out on only valid test items. The data analysis technique applied is hypothesis testing using the t-test (polled variance). Before testing the hypothesis using the t-test, the prerequisite test for analysis includes the normality of the data distribution, and the variance homogeneity test. The normality test was applied using the Kolmogorov-Smirnov technique and the homogeneity test using the Fisher test. The data distribution normality test aims to determine the distribution of PPKn knowledge competency data for each student with a normal distribution or not, while the homogeneity test is intended to find out the difference in true hypotheses that occur due to differences in variance between groups.

\section{Result and Discussion}

The description of the data from the research results describes the acquisition of the post-test results of the civic knowledge competency of a group of students who use the VCT model based on Indonesian folklore (experiment) and a group of students who use conventional learning (control). The recapitulation of the results of the post-test data analysis on the competence of students' knowledge of the two groups is shown in table 03.

Table 03. Summary of Post-Test Civic Knowledge Competency data of the Control and Experimental Group

\begin{tabular}{ccc}
\hline Information & Experiment Group & Control Group \\
\hline Total & 2167,500 & 2280 \\
Average & 83,365 & 76 \\
Variance & 91,471 & 90,76 \\
Standard Deviation & 9,564 & 9,928 \\
Maximum Value & 97,5 & 90 \\
Minimum Score & 65 & 55 \\
\hline
\end{tabular}

Based on the table above, it is converted to a PAP scale of 5 using the calculation of the mean and standard deviation, the following data is obtained in table 04.

Table 04. Guidelines for Scale PAP Conversion 5

\begin{tabular}{cccc}
\hline Percentage of Mastery & Score & Letter Value & Predicate \\
\hline $90-100$ & 4 & $\mathrm{~A}$ & Very Good \\
$80-89$ & 3 & $\mathrm{~B}$ & Well \\
$65-79$ & 2 & $\mathrm{C}$ & Satisfactory \\
$55-64$ & 1 & $\mathrm{D}$ & Less than Satisfactory \\
$0-54$ & 0 & $\mathrm{E}$ & Very Less \\
\hline
\end{tabular}

Based on the average value of the knowledge competency of the experimental group civic obtained $=83,365$. Then it is converted to the KKN knowledge group competency categorization table of the experimental group on PAP Scale 5, and obtained in the Good category. Meanwhile, the average value of the control group civic knowledge competency was obtained $=76$. Then it was converted into the control group CPKn knowledge competency categorization table on PAP Scale 5, and obtained in the satisfactory category.

Whether or not the data distribution of the two groups is normally distributed can be seen by testing the normality of the data distribution using the Kolmogorov-Smirnov technique. At the significance level of 5\%, if the value of $\mid$ Ft-Fs $\mid \leq$ Kolmogorov-Smirnov fable, then the data is normally distributed and vice versa if the value of $\mid$ Ft-Fs $\mid>$ Kolmogorov-Smirnov fable means the data is not normally distributed. The following are the results of the normality test for the data distribution of the two groups in table 05 . 
Table 05. Summary of Test Data Normality and Homogeneity of Variance Post Test for Research Samples

\begin{tabular}{|c|c|c|c|c|c|c|c|c|c|c|}
\hline $\begin{array}{l}\mathbf{N} \\
\mathbf{0}\end{array}$ & Sample & $\mathbf{N}$ & $\begin{array}{c}\text { Maximu } \\
\text { m Value } \\
\mid \text { Ft-Fs } \mid\end{array}$ & $\begin{array}{c}\text { Table } \\
\text { Value } \\
K-S\end{array}$ & $\begin{array}{l}\text { Inform } \\
\text { ation }\end{array}$ & $\mathbf{S}_{1}{ }^{2}$ & $\mathbf{S}_{2}{ }^{2}$ & $F_{\text {count }}$ & Ftable & $\begin{array}{c}\text { Inform } \\
\text { ation }\end{array}$ \\
\hline 1 & $\begin{array}{l}\text { Grde IV SDN } \\
3 \text { Celuk } \\
\text { (exsperimen } \\
\text { t) }\end{array}$ & 26 & 0,090 & 0,259 & $\begin{array}{l}\text { Normal } \\
\text { Distribu } \\
\text { tion }\end{array}$ & 91,471 & & 1,008 & 1,891 & $\begin{array}{l}\text { Homoge } \\
\text { nous }\end{array}$ \\
\hline 2 & $\begin{array}{l}\text { Grade IV } \\
\text { SDN 1 Celuk } \\
\text { (control) }\end{array}$ & 30 & 0,096 & 0,242 & $\begin{array}{c}\text { Normal } \\
\text { Distribu } \\
\text { tion }\end{array}$ & & $\begin{array}{c}90,77 \\
6\end{array}$ & & & \\
\hline
\end{tabular}

After the data distribution normality test was carried out and it was stated that the two sample groups were normally distributed then a homogeneity test was carried out to prove the differences that had previously been obtained using the pollen t-test variants were differences between the two groups, not differences triggered by differences within the group. At the 5\% significance level with degrees of freedom $(\mathrm{dk})$ for the $\mathrm{n} 1-1$ numerator $(26-1=25)$ and dk for the $\mathrm{n} 2-1$ denominator $(30-1=29)$, it was obtained Ftable $=1.891$. From the analysis, it is found that Fcount $=1.008$. This means that Fcount $=1.008$ $<$ F-table $=1.891$ so that the data for the two groups had a homogeneous variance group. Based on the results of the normality test and the homogeneity test of variance, it can be summarized that the two sample groups are normally distributed and have homogeneous variances. Furthermore, hypothesis testing is carried out.

$\mathrm{H}_{0}$ : There is no significant difference in the competency of civic knowledge between groups of students which is learned using the Value Clarification Technique learning model based on Indonesian folklore with groups of students not being taught using the Value Clarification Technique learning model based on Indonesian folklore in grade IV students of SD Negeri Gugus Sukawati VII Gianyar for the 2019/2020 academic year.

The criteria for testing the hypothesis is that if $\mathrm{t}$-count $\leq \mathrm{t}$-table, then $\mathrm{H} 0$ is accepted, and if $\mathrm{t}$-count $>$ $\mathrm{t}$-table then $\mathrm{H} 0$ is rejected. At the $5 \%$ significance level with $\mathrm{dk}=\mathrm{n} 1+\mathrm{n} 2-2$. The following is a recapitulation of the results of hypothesis testing can be seen in table 06 .

Table 06. T-Test Recapitulation of Posttest Research Samples

\begin{tabular}{|c|c|c|c|c|c|c|c|c|}
\hline No. & Sample & $\mathbf{N}$ & DK & $\overline{\boldsymbol{X}}$ & $S^{2}$ & $T_{\text {-count }}$ & $T_{\text {-table }}$ & Conclusion \\
\hline 1 & SDN 3 Celuk & 26 & 54 & 83,365 & $\begin{array}{l}91,471 \\
90776\end{array}$ & 2,880 & 2,005 & $\mathrm{H}_{0}$ rejected \\
\hline
\end{tabular}

The results of the t-test calculation obtained $\mathrm{t}=2.880$ then compared with $\mathrm{t}$-table at a significance level of $5 \%$ and $\mathrm{dk}=26+30-2=54$ then obtained $\mathrm{t}$ table $=2.005$. Based on this, it is obtained that $\mathrm{t}$-count $=2.880 \mathrm{t}$-table $=2.005$, which means that $\mathrm{HO}$ is rejected and Ha is accepted. This proves that there is a significant difference in the Value Clarification Technique learning model based on Indonesian folklore on the knowledge competencies of PPKn for grade IV SDN Gugus Sukawati VII Gianyar for the 2019/2020 academic year. In general, the results of the research carried out have been running according to the objectives of the implementation optimally. From the results obtained, it is known that the two sample groups have the same ability after the experimental group was given action by using the VCT learning model based on Indonesian folklore in thematic learning, especially the civic content experienced an increase which was known from the mean value of the two groups. The mean value of the two groups was a difference of 7,365 with the mean of the experimental group $=83,365$ and the control group $=76$. Not only that, when the learning took place, but the class conditions were also running in a conducive and optimal way. This model fosters student interest in learning and fosters good attitudes in line with the values contained in PPKn learning. So that in the learning process meaningful learning is created. This can be seen from the activities of students in replying to the questions presented by the teacher. Students look enthusiastic in raising their hands when asked questions by the teacher and students look more relaxed in answering and not tense. The difference in the acquisition of civic knowledge competencies between the 
two groups was due to the treatment when given both at the learning step and the different learning processes between the two groups and was influenced by the following factors.

First, the VCT learning model makes it easier for students to clarify/explore and share the content of the material presented, making it easier for teachers to convey messages/meanings of moral values. This requires students to be able to develop the values that exist in themselves in dealing with a problem through a process of analysis then these values are consciously implanted in students so that they can convey or assess quality in others and understand values in life. This is confirmed by the research results from (Sudirman, 2015) which states that VCT can be interpreted as a teaching technique to assist students in finding and determining a value that is considered good in dealing with a problem through the process of analyzing existing values and embedded in students. Second, basically during the learning process students play an active role with their friends in exploring and discovering the moral values found in facing a problem through group or individual discussions. This allows students to independently develop and instill moral values in the realm of the internal side. Furthermore, students will show an active role in independently developing the ability to solve a problem through value analysis. Not only students, but teachers also play a role in planning, fostering, and organizing groups as a means for facilitators so they don't get out of the scope of learning. This is in line with the opinion of (Rachmadyanti \& Rochani, 2017) stated that VCT is a learning model that fosters students' awareness of the values they have, both positive and negative, and then fostered towards improvement or correction.

Third, allow students to innovate to develop curiosity, think creatively, be creative in solving problems. In this case, students are given the freedom to be directly and actively involved in the learning process, starting from choosing a problem given by the teacher to solve the problem in groups or individually. This shows that students can innovate and think critically as they wish in dealing with existing problems through the values then the teacher guides the answers to each student's opinion as a group or individually. In line with (Sariani's, 2016) opinion, This learning provides a meaningful experience by giving students the freedom to choose actions and analyze actions through discussion so that they can build knowledge within themselves, understand mutual differences of opinion, decide the best decisions and foster a high sense of social and togetherness. Fourth, in addition to making students independent and active and creative in developing their knowledge and solving problems at hand. VCT learning based on Indonesian folklore promotes gradual learning, namely, first, freedom in making choices, and freedom to determine in carrying out actions as a result of the actions taken. Second, an attitude of respect, such as a sense of admiration for the value he chooses, so that it becomes his integrity and affirms the values according to his will with confidence and a desire to show them in public. Third, behave in accordance with the value that has been chosen. Value education is very useful in life. Own value is something that people hold personally and are internalized guides in human behavior in the form of values of truth, goodness, and beauty (Sutrisno, 2016).

Fifth, it is different from the control group which was taught using conventional learning. The conventional learning model is a traditional learning method or it is also called the lecture method because this method has always been used as a means of oral communication between teachers and students in the learning and learning process (Lestari \& Sofyan, 2014). In addition, the method used is inseparable from lectures, division of tasks, and exercises as a form of repetition and deepening of teaching material. In learning the teacher dominates the class by delivering material using the lecture method, question and answer, and assignments continuously. This will make students tend to get bored quickly and are not interested in learning material. Learning methods like this will cause the classroom atmosphere to be not conducive so that it impacts on the results of the competency of civic knowledge that are not optimal. In addition, this model is not able to maximize the potential of students. The results of this study have similarities and are strengthened by research conducted by a) (Arni, 2018) get the results that learning with the Value Clarification Technique based on project appraisal models has a good effect on the knowledge competence of the 4th-grade Civics in Elementary School Letda Made Putra 2017/2018 Academic Year. This can be seen from the results of the research obtained, namely that the average student in the experimental group was higher than the average competence of Civics knowledge in the control group (X1 = 0.487> X2 = 0.327), b) (Sudarma, 2017) said that there were significant differences in Civics learning outcomes between groups of students who were taught using the Value Clarification Technique (VCT) learning model based on social problems and groups of students who were taught with conventional learning models in fifth-grade elementary school students in Cluster V, Karangasem District, 2016/2017 Academic Year. This can be seen from the average value of the experimental group $=22.64>$ the control group $=16.84$. c) (Anggraini, 2013) said that there was a significant difference in the character values between students who were taught with the value clarification technique (VCT) learning model assisted by image media and students who were taught with 
conventional learning models in class V students in Cluster VI Tajun. The calculation of the results of this study shows that the average $(\mathrm{X})$ experiment> mean $(\mathrm{X})$ control is $76.35>65.67$. Advice, d) Rahayudhi (2013) states that there is a significant difference in the VCT learning model assisted by Microsoft PowerPoint media on students' Civics learning achievement. The results of the calculation of this study indicate that the experimental group average $=42.50>$ the control group average $=27.10$.

Based on the results of the study that the Value Clarification Technique model based on folklore influences the knowledge competence of civic students in grade IV SDN Gugus Sukawati VII in the academic year 2019/2020. This can be seen from the average value of the experimental group is higher than the control group, namely the mean of the experimental group $X^{-}=83,365$ and the control group $X^{-}=$ 76. Based on the explanation above, findings have theoretical implications that the story-based VCT learning model the people of the archipelago have a positive impact on student learning outcomes. This is because the teacher becomes easier to convey the meaning contained in learning so that students understand the subject matter more easily. The VCT learning model provides a conducive atmosphere during the learning process because students are actively involved in expressing their opinions. Students can solve a problem because they already know the technique of clarifying good grades for themselves. The enthusiasm of students to learn is increasing because the values contained are beneficial for everyday life. Whereas practically the implication of this research can be used as an entry point for teachers and prospective teachers in improving themselves in improving student learning outcomes by paying attention to appropriate learning methods and student motivation to improve student learning achievement. The VCT learning model based on Indonesian folklore is a research innovation that can be used in changing the mindset of students towards classroom learning so that it can run optimally as expected. Besides that, the folklore of the archipelago can give a meaningful impression to students and feel the benefits in everyday life through the values contained there.

\section{Conclusion}

From the results of the overall analysis, it was found that the $t$-count was more than $\mathrm{t}$ table with the mean value of the experimental group being higher than the control group. This proves that the Value Clarification Technique learning model based on the folklore of the archipelago has an effect on the civic knowledge competency of grade IV SDN Gugus Sukawati VII Gianyar for the 2019/2020 academic year.

\section{References}

Adisusilo, S. (2014). Pembelajaran Nilai-nilai Karakter Kontruktivisme dan Value Clarification Technique sebagai Inovasi Pendekatan Pembelajaran Afektif. Jakarta: PT Raja Grafindo Persada.

Agung, A. A. G. (2014). Buku Ajar Metodelogi Penelitian Pendidikan. Malang: Aditya Media Publishing.

Arikunto, S. (2018). Dasar-Dasar Evaluasi Pendidikan. Jakarta: Bumi Aksara.

Arni Rahayuni, N. P., Sri Asri, I. G. A. A., \& Suniasih, N. W. (2018). Pengaruh Model Pembelajaran Pair Check Berbasis Penilaian Kinerja Terhadap Kompetensi Pengetahuan Pkn Siswa Kelas Iv. Mimbar Ilmu, 23(1), 67-75. https://doi.org/10.23887/mi.v23i1.16408

Astawa, I. W. W., Putra, M., \& Abadi, I. B. G. S. (2020). Pembelajaran PPKn dengan Model VCT Bermuatan Nilai Karakter Meningkatkan Kompetensi Pengetahuan Siswa, 3(2), 199-210. http://dx.doi.org/10.23887/jp2.v3i2.25677

Darmadi, H. (2014). Urgensi Pendidikan Pancasila dan Kewarganegaraan Di Perguruan tinggi. Bandung: Alfabeta.

Dr. I Komang Sudarma, S. (2017). Pengaruh Model Pembelajaran Value Clarification Technique (VCT) Bermediakan Video Terhadap Hasil Belajar Pkn Siswa Kelas V. MIMBAR PGSD Undiksha, 5(2). https://doi.org/10.23887/jjpgsd.v5i2.11003

Fitriani, V., \& Sundawa, D. (2016). Penerapan model VCT (Value Clarification Technique) dengan menggunakan media cerita daerah dalam pembelajaran pendidikan kewarganegaraan untuk meningkatkan karakter peserta didik. Jurnal Pendidikan Ilmu Sosial, 25(1), 41-57. https://doi.org/10.17509/jpis.v25i1.3669

Fujiawati, F. S. (2016). Pemahaman Konsep Kurikulum dan Pembelajaran dengan Peta Konsep Bagi Mahasiswa Pendidikan Seni. Jurnal Pendidikan Dan Kajian Seni, 1(1), 16-28. http://dx.doi.org/10.30870/jpks.v1i1.849 
Isnanda, R. (2015). Struktur Dan Nilai-Nilai Pendidikan Dalam Cerita Rakyat Kabupaten Tanah Datar Provinsi Sumatera Barat. Gramatika STKIP PGRI Sumatera Barat, 1(2), 183-192. https://doi.org/10.22202/jg.2015.v1i2.1238

Jayanta, I. N. L., \& Susiani, K. (2017). Cerita Rakyat Berbasis Mobile Untuk Anak Sekolah Dasar. Jurnal Ilmiah Sekolah Dasar, 1(4), 304. https://doi.org/10.23887/jisd.v1i4.13768

Kd. Dewi Anggarini, I Nym. Murda, I. W. S. (2013). Pengaruh Model Pembelajaran Value Clarification Technique Berbantuan Media Gambar Terhadap Nilai Karakter Siswa Kelas V SD Gugus VI Tajun. Mimbar PGSD, 1 (1), 1-12. http://dx.doi.org/10.23887/jjpgsd.v1i1.865

Kristanto, M. (2014). Pemanfaatan cerita rakyat sebagai penanaman etika untuk membentuk pendidikan karakter bangsa. Mimbar Sekolah Dasar, 1(April), 59-64. https://doi.org/10.17509/mimbarsd.v1i1.864

Kurniadi, E., Darmowijoyo, D., \& Pratiwi, W. D. (2020). Analisis Kemampuan Pemahaman Konsep Dasar Mahasiswa dalam Mengidentifikasi Karakteristik dan Menyelesaikan Soal Pemodelan Matematika. Jurnal Gantang, 5(1), 9-18. https://doi.org/10.31629/jg.v5i1.299

Lestari, L., \& Sofyan, D. (2014). Perbandingan kemampuan pemecahan masalah siswa dalam matematika antara yang mendapat pembelajaran matematika realistik (PMR) dengan pembelajaran konvensional. Jurnal Pendidikan Matematika, 3, 95-108. https://journal.institutpendidikan.ac.id/index.php/mosharafa/article/view/mv3n2_4

Mirnasulistyawati, Armelia, \& Afdal. (2013). Anlisi Penerapan Kurikulum 2013 Dalam Rangka Meningkatkan Kualitas Pembelajaran.

Nurdyansyah, \& Fahyuni, E. F. (2016). Inovasi Model. Nizmania Learning Center.

Nurjanah, \& Marlianingsih, N. (2015). Analisis Butir Soal Pilihan Ganda Dari Aspek Kebahasaan. Jurnal $\begin{array}{lll}\text { Ilmu Kependidikan, 2(1), 197-202. } & \text {. }\end{array}$ https://journal.lppmunindra.ac.id/index.php/Faktor/article/view/377

Rachmadyanti, P., \& Rochani, R. (2017). Pengembangan Social Skill Siswa Sekolah Dasar Melalui Teknik Pembelajaran Vct (Value Clarification Technique). DWIJA CENDEKIA: Jurnal Riset Pedagogik, 1(2), 70-78. https://doi.org/10.20961/jdc.v1i2.15290

Rahayudhi, Y. (2013). Pengaruh Model Pembelajaran VCT Berbantuan Media Microsoft Powerpoint Terhadap Prestasi Belajar Pkn. Jurnal mimbar PGSD Universitas Pendidikan Ganesha. http://dx.doi.org/10.23887/jjpgsd.v1i1.736

Risvanelli. (2017). Peningkatan Hasil Belajar dan Aktivitas Siswa Kelas V Menggunakan Pendekatan Value Clarification Technique ( VCT ) Pada Pembelajaran PKn di SDN 24 Batang Anai Kabupaten Padang Pariaman. Jurnal Penelitian Pendidikan Indonesia, 3, 44-56. https://doi.org/10.29210/02017116

Sariani, N. K. D., Dantes, N., \& Parmiti, De. P. (2016). Pengaruh Model Pembelajaran Value Clarification Technique ( Vct ) Terhadap Sikap Sosial Dan Hasil Belajar. E-Jurnal PGSD Universitas Pendidikan Ganesha, 4(1), 1-10. http://dx.doi.org/10.23887/jjpgsd.v4i1.7463

Sudirman. (2015). Penanaman nilai dalam pembelajaran PKN melalui inovasi pendekatan value clarification technique (VCT) di sekolah. Jurnal Ilmu Sosial Mamangan, 2, juli-desember. https://doi.org/10.33559/mi.v13i5.1367

Sugiyono. (2016). Statistika Untuk Penelitian. Bandung: Alfabeta.

Sutrisno. (2016). Berbagai Pendekatan dalam Pendidikan Nilai dan Pendidikan Kewarganegaraan. Jurnal Dimensi Pendidikan Dan Pembelajaran;, 5, 26-37. https://doi.org/10.24269/dpp.v4i1.56

Taniredja, Tukiran, D. (2017). Model-model Pembelajaran Inovotaif dan Efektif. Bandung: Alfabeta.

Yusuf, W. F. (2018). Implementasi Kurikulum 2013 (K-13) Pada Mata Pelajaran Pendidikan Agama Islam Dasar $(\mathrm{Sd})$. Jpai, $3(20)$,

263-278. https://jurnal.yudharta.ac.id/v2/index.php/pai/article/view/1097 